\title{
Ideational Meanings of Teachers' Utterances in Reading and Writing Classes
}

Sri Mulatsih, Mursid Saleh, Warsono, Issy Yuliasri

English Department Semarang State University, Semarang, Indonesia

Email: sri.mulatsih@dsn.dinus.ac.id

How to cite this paper: Mulatsih, S., Saleh, M., Warsono, W., \& Yuliasri, I. (2018). Ideational Meanings of Teachers' Utterances in Reading and Writing Classes. International Journal of Language Teaching and Education, 2(3), 275-285. https://doi.org/10.22437/ijolte.v2i3.5689

Accepted: October 18, 2018

Published: November 30, 2018

Copyright (C) International Journal of Language Teaching and Education. This work is licensed under the Creative Commons Attribution InternationalLicense (CC BY 4.0).

http://creativecommons.org/licenses/by/4 $.0 /$

(c) (i)

\begin{abstract}
This study is aimed at describing the ideational meanings of teachers' utterances in Reading and Writing classes. It reveals what processes, participants and circumstances are found in the teachers' utterances. The data were taken from the Reading and Writing classes conducted at a university in Semarang city. The data were collected by video recording the teaching and learning processes in Reading and Writing classes, then they were analyzed by segmenting the utterances into clauses; identifying the process, participants, and circumstances; classifying the processes, participants and circumstances based on their type; and interpreting the data. The results showed that the processes mostly found in the teachers' utterances in Reading class are relational ones with carrier and attribute as participants, the second are mental processes with sense and phenomenon as the participants, while in those of Writing class are material with actor and goal as participants and the second are relational with carrier and attribute as participants. Relational processes are dominant in Reading class because the teacher explained many terms or vocabularies found in the text to make the students really understand them. That material processes are dominant in Writing class is caused by the fact that in Writing class the teacher often asks the students to do some actions like writing or doing something.
\end{abstract}

\section{Subject Areas}

Systemic Functional Linguistics

\section{Keywords}

Ideational Meanings, processes, participants, Reading and Writing classes

\section{Introduction}

Reading and writing are two different skills. Reading is considered as a receptive skill, while writing is a productive one. The way to teach these two skills should also be different. Reading is a complex cognitive process of under-standing symbols to construct or derive meaning. When we read, we use our eyes to receive written symbols (letters, punctuation marks, and spaces) and we use our brain to convert them into 
words, sentences, and paragraphs that communicate something to us. Reading can be silent (in our head) or aloud (so that other people can hear). As mentioned above, Reading is a receptive skill - through reading we can receive some information.

Writing, on the other hand, is fundamental in learning to think and press one's thought in ways that reach others. The ability to use language coherently and powerfully and to write in ways that connect with others across cultural boundaries and within communities is essential to active citizenship and to success in almost profession. [1]

Writing is not only a tool for communication, but it also serves as a means of learning, thinking, and organizing knowledge or ideas. In other words, writing is a complex activity involving some stages of composition task completion [2]. Undoubtedly, this skill particularly in an EFL context (i.e., Indonesia) has been considered one of the most difficult skills for learners to master [3]. The difficulties are due not only to the need to generate and organize ideas using the appropriate choices of vocabulary, sentence, and paragraph organization but also to turn such ideas into a readable text along with a rhetoric pattern [4]. Moreover, Indonesian learners often encounter difficulties in transferring ideas from their native language--Indonesian into the target language--English. This case calls for teachers' greater attention to help the learners to be successful in a writing skill.

In teaching Reading and Writing the teachers usually use several modes (resources of meanings) such as spoken languages (utterances), written languages, pictures or gestures [5]. Teachers' utterances become very important in both classes because they can support the understanding of the students toward the topics given in those classes. Since teachers' utterances are also considered as the sources of meaning, based on Systemic Functional Linguistics, they contribute meanings. The meanings can be ideational, interpersonal, or textual. The focus of this study is ideational meanings of their utterances in teaching Reading and Writing. It is aimed at figuring out the processes, participants, and circumstances used by the teachers in Reading and Writing classes.

There are several previous studies that discuss about ideational meanings. Two of them are the ones conducted by [14], and [15). [14] discusses about the ideational metafunction in Joseph Conrad's Heart of Darkness, a critical discourse analysis. The results show that the dominant process used in that novella are material and actor as the participants. This finding is in line with the ideology of the author of the novella that is against the racist and imperialist. [15] discusses about the ideational meaning of Butanes folklore, a systemic functional linguistics study. The results show that material process and actor as the participant is dominant in this study. This shows that the life of Butonese was oriented with the action which represented the horizontal dimension. While the dominancy of actor as the participant shows that Butonese people are mostly working people.

The difference between those two previous studies with this study lies in the 
kinds of data. Both studies use written data, while this study uses spoken ones. Those two previous studies use literary data, those are novella and folklore, while this study uses data taken from classroom discourse. It is expected that this study will give the insight to the teaching and learning processes, especially in teaching reading and writing.

\section{Literature Review}

In this part there are several theories that are presented, they are Systemic Functional Linguistics, Ideational meanings which covers processes, participants, and circumstances, and teaching Reading and Writing.

\subsection{Systemic Functional Linguistics (SFL)}

Systemic Functional Linguistics is a study that is proposed by reference [6]. It is an approach on a language which is centered on how people use language with each other in accomplishing every social life. It studies about how the meanings of the texts are realized because of the process of making meaning by choosing. It focuses and concerns on the meaning of the language that is based on the context.

SFL has three different systems of type meanings to understand the meaning of the text according to the context of situation related with the three items from previous paragraph (Field, Tenor, and Mode). Those systems will help on understanding the topic of the text, knowing how the person produces the text and the form of the text whether it is written or spoken.

In SFL, since language is viewed as a resource for making meanings, there are three different types of meaning in language, they are ideational meaning, interpersonal meaning, and textual meaning. These types of meaning are called three strands of meaning. Reference [6] says that the fundamental components of meaning in language are functional ones. The first function is the interpersonal function, the second one is ideational, and the third one in textual [7]. These functional components are called metafunctions. Furthermore, Halliday says that Functional grammar is based on the premise that language has two major functions, metafunctions, for its users, it is a means of reflecting on things - though the only things it is possible to act on by means of a symbolic system such as languages are humans (and some animals). Reference [6] calls these two functions the ideational content' function, and interpersonal function. Since the focus of this study is ideational meanings, the writers will explain the ideational meanings in detail in the following part.

\subsection{Ideational Meanings}

Ideational metafunction is used to represent experience [8]. Ideation is concerned with how our experience of reality, material and symbolic reality - is construed in discourse. While reference [9] describe the ideational meaning as follows: Ideational meaning is meanings about phenomena - about things (living and non-living, abstract and concrete), about goings on (what the things are and do) and the circumstances 
surrounding these happenings and doings. These meanings are realized in wordings through Participants, Processes, and Circumstances.

The ideational meanings, meanings about things and ideas, are realized in the clause by options from Transitivity that can be broken down into three functional constituents, they are processes, participants, and circumstances. Reference [7] states that transitivity is the interpretation in language of process, the participants therein, and the circumstantial features associated with them.

\section{Processes}

The core or the nucleus of the clause as representation of experience is the process. The process represents the happening or event. The clause is on about, whether it is a matter of a 'happening', 'doing', 'thinking', 'saying', 'being', 'having', etc. The term 'process' is understood in a very broad sense, to cover all phenomena to which a specification of time may be attached - in English, anything that can be expressed by a verb, whether physical or not, state, or relation.

Process may be of different types and involve different numbers and kind of participants [7]. While reference [9] maintains that processes are central to transitivity and realized by verbs. It is supported by the statement given by reference [10] that a process is realized in the grammar by means of a verbal group, which is either word, belonging to the class verb, or a group of words with a class verb word as the head or nucleus of the group.

According to reference [9], there are seven types of processes. The types of processes can be seen on table 1 .

Table 1. Seven Types of Process

\begin{tabular}{|l|l|l|}
\hline Material & Doing & Bodily, physically, materially \\
Behavioral & Behaving & physiologically and psychologically \\
Mental & Sensing & emotionally, intellectually, sensory \\
Verbal & Saying & lingually, signaling \\
Relational & Being & equal to, or some attribute of \\
Existential & Existing & there exists \\
Meteorological & Weathering & \\
\hline
\end{tabular}

\section{Participants}

Participants represent things or people involved in carrying out the process or things or people affected by process. According to reference [10] a participant can be a person, a place, or an object (this is the notion of "thing ness"), and in the grammar of a clause participant is most commonly realized by nominal group. For instance, "He kicked the cat" is a clause in which he and the cat are realized by nominal group.

Furthermore [5] elaborated the potential participant roles in each process as follows: The potential roles in material processes are an actor (or doer of the process), a goal (or thing affected by the process), a range (or thing unaffected by the process), a 
beneficiary of the process; in mental processes are sense (or Doer of the process) and phenomenon; the main participant in behavioral process is the behaver, in verbal processes are sawyer (or Doer of the process) and receiver (addressee of the speech), target (the participant which is the object of the talk), and verbiage; in existential processes the participant known as the existent; while in relational attribute clauses the participant carrying the characteristics is known as attributive and in relational identifying are Token and Value.

\section{Circumstances}

Circumstance is any peace of circumstantial information about the process within its own clause. Circumstances are realized by adverbial groups, prepositional phrases and even by nominal group. Circumstances are usually answer the question such as where, when, why, how, how many etc. [10]. Circumstances are divided into many kinds. As stated in reference [9], circumstances are divided into seven kinds. They are time (temporal); place (spatial); manner, which consists of means, quality, and comparison; cause including reason, purpose, and behalf; accompaniment; matter and the last one is role.

\subsection{Teaching Reading and Writing}

The purpose for reading also determines the appropriate approach to reading comprehension. A person who needs to know whether she can afford to eat at a restaurant needs to comprehend the pricing information provided on the menu but does not need to recognize the name of every appetizer listed. A person reading poetry for enjoyment needs to recognize the words the poet uses and the ways they are put together but does not need to identify main idea and supporting details. However, a person using a scientific article to support an opinion needs to know the vocabulary that is used, understand the facts and cause-effect sequences that are presented, and recognize ideas that are presented as hypotheses and givens.

Teaching writing is a complex problem. It requires teachers with a great interest as well as professionalism in writing activities. Not, many teachers are interested in teaching writing, for they will have lots of burden on them correcting the students' writing from time to time. Besides, most EFL students don't like writing. Often, they reach university level without any experience on writing compositions in English. This reality is, of course, an irony of education outcome since no one will doubt how important writing skill is.

Teaching Reading and Writing can be done by several approaches, one of them is by genre-based approach. According to reference [12], genre-based approach is defined as the way to language and literacy education that combines an understanding of genre and genre teaching together in the writing /reading class.

In genre-based approach, there are four stages that should be done, they are build- 
ing knowledge of the field (BKOF), modelling of text, joint construction, and independent construction [13]. BKOF is the point at which overall knowledge of the cultural and social context of the topic is built and developed. Modelling involves introducing the learners to a model of the genre they will be writing/reading. In this stage, there is explicit focus on analyzing the genre through a model text related to the course topic. At joint construction stage, the aim is for the teachers to work with the learners to construct a similar text. Independent construction stage occurs only after group or pair construction has shown that the learners have gained control of the field and the mode.

\section{Method}

This method consists of research design, source of data, participants, unit of analysis, technique of data collection, and technique of data analysis.

This study is designed as a descriptive qualitative one that is intended to describe the ideational meanings of teachers' utterances in Reading and Writing classes. The source of the data is the teaching and learning process in two English classrooms, Reading and Writing classes, in an English Department of a university in Semarang. Both Reading and Writing classes use genre-based approach in the teaching and learning process. The text taught by both teachers is procedure one. The unit of analysis in this study are the clauses found in teachers' utterances in Reading and Writing classes. The participants are the lecturers of Reading and Writing classes. The data of this study were collected by recording the teaching and learning processes of Reading and Writing classes and transcribing the teachers' utterances. The data were analyzed using the framework proposed by [5] with the following steps: segmenting the utterances into clauses, identifying the processes, participants, and circumstances in every clause, classifying the processes, participants, and circumstances based on their types, interpreting the data and drawing conclusion.

\section{Finding and Discussion}

As mentioned in the previous part, ideational meanings of teachers' utterances in Reading and Writing classes are realized in processes, participants, and circumstances the teachers used in teaching and learning processes. The processes they use can be seen in table 2 below:

Table 2. Processes in Teachers' Utterances in Reading and Writing Classes. 


\begin{tabular}{cccccc}
\hline & \multirow{2}{*}{ Types of } & \multicolumn{2}{c}{ Reading Class } & \multicolumn{2}{c}{ Writing Class } \\
\cline { 3 - 6 } No & Processes & $\Sigma$ & $\%$ & $\Sigma$ & $\%$ \\
\cline { 3 - 6 } & Material & 48 & 16,27 & 69 & 33,99 \\
2 & Mental & 63 & 21,35 & 27 & 13,30 \\
3 & Verbal & 32 & 10,84 & 42 & 20,68 \\
4 & Behavioral & 18 & 6.10 & 7 & 3,44 \\
5 & Relational & 127 & 43,05 & 54 & 26,60 \\
6 & Existential & 7 & 2,37 & 4 & 1,97 \\
\hline \multicolumn{2}{c}{ Total } & 295 & 100 & 203 & 100 \\
\hline
\end{tabular}

Table 2 shows that the most dominant process used by the teacher in Reading class is relational (43,03\%), and the second is mental (21,35\%). Relational processes are used mostly by the teacher in this class because the teacher often explained several difficult terms or vocabularies found in the text. This was done to make the students really understand the meanings of the terms. The second processes used frequently by the teacher in Reading class is mental since the teacher often asked the students' understanding about the text by using mental processes. In Writing class, the most dominant process is material, and the second is relational. Material process is mostly used in Writing class because the teacher often asks the students to do some doing verbs.

Table 3. Participants in Teachers' Utterances in Reading and Writing Classes

\begin{tabular}{|c|c|c|c|c|c|}
\hline \multirow[b]{2}{*}{ No } & \multirow{2}{*}{ Types of Participants } & \multicolumn{2}{|c|}{ Reading Class } & \multicolumn{2}{|c|}{ Writing Class } \\
\hline & & $\Sigma$ & $\%$ & $\Sigma$ & $\%$ \\
\hline 1 & Actor-Goal & 48 & 16,27 & 69 & 33,99 \\
\hline 2 & Sense-Phenomenon & 63 & 21,35 & 27 & 13,30 \\
\hline 3 & Sayer-verbiage & 32 & 10,84 & 42 & 20,68 \\
\hline 4 & Behaver-behavior & 18 & 6.10 & 7 & 3,44 \\
\hline 5 & Carrier-attribute & 127 & 43,05 & 54 & 26,60 \\
\hline 6 & Existential-existent & 7 & 2,37 & 4 & 1,97 \\
\hline \multicolumn{2}{|r|}{ Total } & 295 & 100 & 203 & 100 \\
\hline
\end{tabular}

Table 3 shows that in line with the processes used, the dominant participant found in Reading Class is carrier and attribute, and the second position is sense and phenomenon. In Writing class, the dominant participant is actor and goal, and the second rank is carrier and attribute.

Table 4. Circumstances in Teachers' Utterances in Reading and Writing Classes

\begin{tabular}{cccccc}
\hline \multirow{2}{*}{ No } & \multirow{2}{*}{$\begin{array}{c}\text { Types of Cir- } \\
\text { cumstances }\end{array}$} & \multicolumn{2}{c}{ Reading Class } & \multicolumn{2}{c}{ Writing Class } \\
\cline { 3 - 6 } & & $\Sigma$ & $\%$ & $\Sigma$ & $\%$ \\
\hline 1 & Place & 3 & 18,75 & 4 & 23,52 \\
2 & Time & 5 & 31,25 & 2 & 11,76 \\
3 & Manner & 6 & 37,5 & 8 & 47,05 \\
4 & Cause & 2 & 12,5 & 3 & 17,64 \\
\hline & & 16 & 100 & 17 & 100 \\
\hline
\end{tabular}

Table 4 shows that the circumstances of manner are dominant in both Reading and Writing classes. It happens because both teachers explain some terms or give the 
instruction by using some circumstances of manner to make the explanation or instruction clear.

\section{Relational Processes}

As stated in the previous part, relational processes are dominant both in Reading and Writing because this process is usually used to ask, to explain or to give the definition of certain terms to make the students understand those terms. The following are the examples of relational processes in Reading and Writing classes.

(1) What is the text about? (source: Reading class)

\begin{tabular}{|l|c|c|}
\hline What & Is & the text about? \\
\hline attribute & $\begin{array}{c}\text { Relational process: } \\
\text { attributive }\end{array}$ & carrier \\
\hline
\end{tabular}

(2) It is a fiber glass. (source: Reading class)

\begin{tabular}{|l|l|c|}
\hline It & Is & a fiber glass \\
\hline Carrier & $\begin{array}{c}\text { Relational process: } \\
\text { attributive }\end{array}$ & attribute \\
\hline
\end{tabular}

(3) It has an instruction in it. (source: Reading class)

\begin{tabular}{|l|l|l|l|}
\hline It & Has & an instruction & in it \\
\hline Token & $\begin{array}{l}\text { Relational process: } \\
\text { identifying }\end{array}$ & $\begin{array}{l}\text { value } \\
\text { of place }\end{array}$ \\
\hline
\end{tabular}

(4) The social function of procedure text is how something is accomplished. (source: Writing class)

\begin{tabular}{|l|l|l|}
\hline $\begin{array}{l}\text { The social function of } \\
\text { procedure text }\end{array}$ & is & how something is accomplished \\
\hline Carrier & $\begin{array}{l}\text { Relational pro- } \\
\text { cess: attributive }\end{array}$ & attribute \\
\hline
\end{tabular}

(5) The main characteristics of the procedure text is the steps. (source: Writing class)

\begin{tabular}{|l|l|l|}
\hline $\begin{array}{l}\text { The main characteristics } \\
\text { of the procedure text }\end{array}$ & is & the steps \\
\hline Carrier & $\begin{array}{l}\text { Relational process } \\
\text { attributive }\end{array}$ & attribute \\
\hline
\end{tabular}

\section{Material processes}

Material processes are dominantly used in Writing class because in teaching Writing the teacher needs to tell the students some doing activities such as reading, writing etc. The following are the examples of material processes used by the teacher in Writing class.

(6) This morning we are going to discuss about procedure text. (source: Writing 
class)

\begin{tabular}{|l|l|l|l|}
\hline This morning & we & are going to discuss about & procedure text \\
\hline Circa of time & actor & Material process & goal \\
\hline
\end{tabular}

(7) We cannot do it ourselves. (source: Writing class)

\begin{tabular}{|l|l|l|l|}
\hline We & cannot do & It & ourselves \\
\hline Actor & Material process & Goal & Circ. of manner \\
\hline
\end{tabular}

(8) I have read several books before. (source: Writing class)

\begin{tabular}{|l|l|l|l|}
\hline$I$ & have read & several books & before \\
\hline Actor & Material process & Goal & Circ. of time \\
\hline
\end{tabular}

\section{Mental Processes}

Mental processes are also dominant used by the teacher in Reading class to know the students' perception and understanding about the text being explained. The examples of mental process can be seen below:

(9) Please look at the text. (source: Reading class)

\begin{tabular}{|l|l|}
\hline Please look at & at the text \\
\hline Mental process & phenomenon \\
\hline
\end{tabular}

(10) What you think about the text? (source: Reading class)

\begin{tabular}{|l|l|l|l|}
\hline What & You & think about & the text \\
\hline & sense & Mental process & phenomenon \\
\hline
\end{tabular}

(11) Why it needs instruction? (source: Reading class)

\begin{tabular}{|l|l|l|l|}
\hline Why & It & needs & Instruction \\
\hline & sense & Mental process & Phenomenon \\
\hline
\end{tabular}

(12) Now you understand the definition of this word. (source: Reading class)

\begin{tabular}{|l|l|l|l|}
\hline Now & You & understand & the definition of this word \\
\hline $\begin{array}{l}\text { Circ. of } \\
\text { time }\end{array}$ & sense & $\begin{array}{l}\text { mental pro- } \\
\text { cess }\end{array}$ & Phenomenon \\
\hline
\end{tabular}

In examples (9), (10), (11), and (12) mental processes such as look at, think about, needs, and understand are used by the teacher to make the students pay attention of the materials and to ask the students' perception of the materials being given in the classroom.

\section{Conclusion}

Based on the previous discussion, it can be concluded that:

a. The dominant process used by the teacher in Reading class is relational process with carrier and attribute as the participants, and the second one is mental with sense and phenomenon as the participants, while in Writing class, the dominant process used by the teacher is material with actor and goal as the participants, and the second is relational with the carrier and attribute as the participants. The 
dominancy of relational process in reading class is caused by the context that in Reading class there are several difficult terms or words that the students don't understand, and the teacher tries to explain the definition or the meaning of those terms. Those material processes are used mostly in Writing class because in Writing class the teacher asks and shows the students to make and write some doing activities.

b. The circumstances that are dominantly used for both teachers in Reading and Writing classes is circumstances of manner because both teachers want to explain something clearly by using that circumstances.

\section{References}

[1] Foong, K.P. (1999). Teaching writing: A look at purposes, writing tasks, and implications.The English Teacher, 28. Retrieved on December 17 , 2014, from http://www.melta.org.my/ET/1999/main3.html(Foong)

[2] Watskins, P. (2004). Writing. English Teaching professional Issue, 30, 40-41.

[3] Lewitt, P.J. (1990). How to Cook a Tasty Essay. English Teaching Forum. Vol. 26, $17-23$.

[4] Richards, J.C., \& Renandya, W.A. (2002). Methodology in language teaching: An anthology of current practice. Cambridge: Cambridge University Press.

[5] Bull, G \& Anstey, M (2010 a), Evolving Pedagogies; Reading and Writing in a Multimodal World, Education Services Australia, Melbourne.

[6] Halliday, M.A.K., \& Matthiessen, C. (1994). Halliday's introduction to functional grammar (fourth edition). London: Routledge.

[7] Kress, G. (2009). Multimodality: a Social Semiotic Approach to Contemporary Communication, London: Routledge.

[8] Martin, J., \& Rose, D. (2003). Working with Discourse: Meaning beyond the clause. New York: Continuum.

[9] Gerot, Linda and Wignell, Peter. (1994). Making Sense of Functional Grammar. New South Wales: Gerd Stabler.

[10] Butt, D., Fahey, R., Spinks, S., \&Yallops, C. (2001). Using functional grammar: An explorer's guide (Second edition). Sydney: NCELTR, Macquarie University.

[11] Derewianka, Beverly. (1990). Exploring How Texts Work. Australia: Primary English Teaching Association

[12] Hammond, Jennifer and Derewianka, B. (2001). Genre. In Carter, R. And Nunan, D. The Cambridge Guide to Teaching English to Speakers of Other Language. (pp.186-193). Cambridge University Press.

[13] Hyland, Ken. (2004). Genre and Second Language Writing. USA: The University of Michigan Press.

[14] Alaei. Mahya, Ahangin. Saedah. 2016. A Study of Ideational Metafunction in Joseph Conrad's Hearth of Darkness: A Critical Discourse Analysis. English Lan- 
guage Teaching Journal. Vol. 9 No. 4 2016. Canadian Center of Science and Education.

[15] Gusnawaty, Yastiana. Yuli, Yassi. Abdul Hakim. 2017. Ideational Meaning of Butonese Folklore: A Systemic Functional Linguistic Study. Rupkhata Journal on Interdisiplinary Studies in Humanities. Vol. IX No. 1.2017. 